\title{
The EU's Consular Protection Policy from the Administrative Law Perspective
}

\author{
Erzsébet Csatlós \\ University of Szeged, Faculty of Law and Political Science, Hungary \\ drcsatloserzsebet@gmail.com \\ https://orcid.org/0000-0001-8129-6189
}

Received: 2. 1. 2020

Accepted: 20. 3. 2020

\section{ABSTRACT}

The European Administrative Space has grown into a multi-level administrative structure characterised by the horizontal and vertical cooperation of all its levels. The sole executive responsibility of Member States' administrations has been substituted by cooperative networks of direct and indirect level authorities due to the growing number of composite procedures. Thus, consular protection policy has evolved from an intergovernmental regime to a special European administration field. The multi-level institutionalisation of the execution and evaluation of European policies is a coherent system compared to the obligation de résultat of the Member States once associated with the implementation of the acquis. Therefore, the article examines what constitutes European administration in this and other policy fields and what represents its structural and procedural law sides. The EU consular protection policy as such is a unique policy at the crossroads of international law, domestic law and different level of EU law. Europeanisation of a certain policy often means a sort of harmonisation of substantial law; however, in case of consular protection, it is not targeted. Consular protection policy is Europeanised in structural and procedural aspects under the auspices of fundamental right protection and ends up in the creation of the European administration for the policy. The article thus highlights the process of establishing European administration and calls attention to possible problems of legal application while offering theoretical bases to eliminate them.

Keywords: EU law, European administration, EU citizenship, consular assistance, administrative cooperation, soft law 


\section{Introduction: from intergovernmentalism to the establishment of European administration}

The Maastricht Treaty declared among EU citizenship rights that "[e]very citizen of the Union shall, in the territory of a third country in which the Member State of which he is a national is not represented, be entitled to protection by the diplomatic or consular authorities of any Member State, on the same conditions as the nationals of that State (...)" (Maastricht Treaty, art. 8c al.1).

Given the strong political and international public law frames of consular relations of a State, the policy entirely belonged to the intergovernmental second pillar the European integration. As the Member States were also called to adopt "the necessary rules among themselves and start the international negotiations required to secure this protection," (Maastricht Treaty, art. 8c al. 2) the Council members, in fact in the form of a simplified treaty, decided upon the most important situations when consular assistance is required for each other's citizens (95/553/EC Decision, art. 5.) according to the consular law of the requested consular authority's domestic law (Poptcheva, 2014, pp. 171-173). Then, a common format for emergency travel document (96/409/ CSFP) was also introduced to facilitate the proceedings, but the harmonisation of consular law was not (and could not be) aimed; the obligation required only equal treatment and casual cooperation to that end was settled in guidelines, ${ }^{1}$ that is soft law (cf. Ştefan, 2017, p. 203).

Elementary changes entered into force by the Lisbon Treaty when the EU Charter strengthened the right to get consular assistance as a fundamental one (EU Charter, art. 46) among others that guarantee procedural rights (see esp. EU Charter, art. $7 ; 8 ; 21,33(1), 41 ; 42 ; 47)$ when EU law is applied in their cases. It also established new EU legislative competence to regulate coordination and cooperation to the evaluation of TEU Art. 23, which has launched a new era in European consular protection policy. Based upon it, Council Directive (EU) 2015/637 of 20 April 2015 (Directive 2015/637) entered into force on $1^{\text {st }}$ May 2018 and Council Directive 2019/997 of 18 June 2019 on the new emergency travel document have opened the gate for significant issues of European administration of consular protection: (a) structural law dimension by incorporating the consular protection policy under the room of direct level of administration and also (b) procedural law aspects of service as the result of a cooperation mechanisms among primarily consular authorities of the Member States but potentially complemented by other actors. In addition, all new provisions shall be interpreted without prejudice to Member States sovereignty over the domestic normative content of consular protection and their international relations with third States' procedural and structural law. (Directive 2015/637, art. 7.2; Directive 2019/997, art. 7. 1. (d), (e); 2 (c)) The

1 See, Consular Guidelines on the protection of EU citizens in third countries adopted by the COCON and endorsed by the PSC 15613/10, of 5 November 2010.; Guidelines for further implementing a number of provisions under Decision 95/553/EC. Brussels, 24 June 2008, 11113/08, PESC 833 COCON 10.; Guidelines on consular protection of EU citizens in third countries. Brussels, 5 November 2010, 15613/10. COCON 40 PESC 1371.; Guidelines on Consular Protection of EU Citizens in Third Countries. PESC 534 COCON 14 10109/2/06 REV 2 Brussels, 16 June 2006. 
major motive behind the policy and all its development is to better serve citizens while it is building up as an area of European administration must catch up with the requirements of the rule of law. During the past decades, the normative background was rather soft law (Verdier, 2009, p. 167; Senden, 2005, p. 82), although the requirements vis-à-vis European administration is clear: it shall be based on the rule of law.

\section{Role of rule of law: questions to be answered}

International institutions should be understood as concretizations of general principles of public law formulated in the tradition of liberal constitutionalism and adapted to the structures and requirements of multilevel systems (von Bogdandy, 2008, p. 1921). Under this interpretation and its own objective to "have the support of an open, efficient and independent European administration" (TFEU, art. 298 al. 1), the EU's attachment to the principles of the rule of law requires to establish its administration also to be in conformity with its elements.

Being one of the major values, it is an „umbrella principle with formal and substantive components or sub-principles" (Pech, 2009, p. 53.) originated from the traditional principles recognized throughout the national legal orders of its Member States: legality, legal certainty, confidence in the stability of a legal situation, and proportionality (von Danwitz, 2014, p. 1314). The list is not exhaustive, and as there is not inclusive interpretation on the rule of law, theoretical analyses seeking for the administrative law standards support an exhaustive approach which also, add non-discrimination; the right to a hearing in administrative decision-making procedures, interim relief, fair conditions for access of individuals to administrative courts, non-contractual liability of the public administration to core elements of the rule of law. Basically, the main administrative law principles subtracted and accepted as standard are reliability and predictability (legal certainty); openness and transparency; accountability; and efficiency and effectiveness (SICMA 27, 2009, p. 8; Bauer and Trondal, 2015, p. 10; see also different definitions in Møller and Skaaning, 2014, pp. 1627). These are legal principles whose main function is the attribution of the binary qualification of legal/illegal in the light of overarching values and ignoring them leads to the loss of legitimacy (von Bogdandy, 2008, p. 1912), no matter which level of European administration is on a charge, they shall be respected, and they shall prevail. Direct and indirect administration form relatively separated organisational systems with their own institutional norms and are mainly connected via governance issues but the number of policies that requires daily and constant cooperation is growing, although the interaction sphere is out of the scope of legislation and comprehensible practice that may give rise to codification, as highlighted in the ReNEUAL Model Rules work (ReNEUAL Model Rules Book VI, p. 265-266). Meanwhile, the system formed by the two levels also assumes the principle of administration through law, which means that public administration ought to discharge its responsibilities according to law (SIGMA 27, 1999, p. 9). 
Therefore, when the implementation of the EU policies and application of EU law are viewed through the prism of rule of law, it shall be examined in a (a) functional perspective to see if rights and policy objectives can be pursued and balanced against each other; (b) an organisational perspective to check that institutions and bodies are equipped with means to pursue the tasks; (c) a procedural perspective to detect if the core values and rights are fulfilled and realised through procedural provisions and forms of act; and (d) an accountability perspective to verify if acts are reasoned and justified, and that there are proper review and control of activities (cf. Hofmann, 2012, p. 4).

The European administration relies on two levels: on a direct one with the competent institutions and organs of the $\mathrm{EU}$ and the indirect one that encompasses the Member States' administration to execute the acquis. The two levels are connected with a link that depends on the Europeanisation of the policy and the legislative competences of the EU (vertical relationship) that empowers direct level with structural influence above the indirect one. It is completed with the necessary teamwork connection of the competent national authorities of Member States (horizontal relationship) proceeding in the same composite procedure. Institutional and procedural law questions are revealed to determine the relationship among the actors which often regularize in a different type of networks (Corkin and Boeger, 2014, p. 223) that influences jurisdiction and applicable law issues and this way the enforceability of the right embodied in article 46 of the EU Charter. [see figure no. 1.]

Figure 1: Schema of European administration

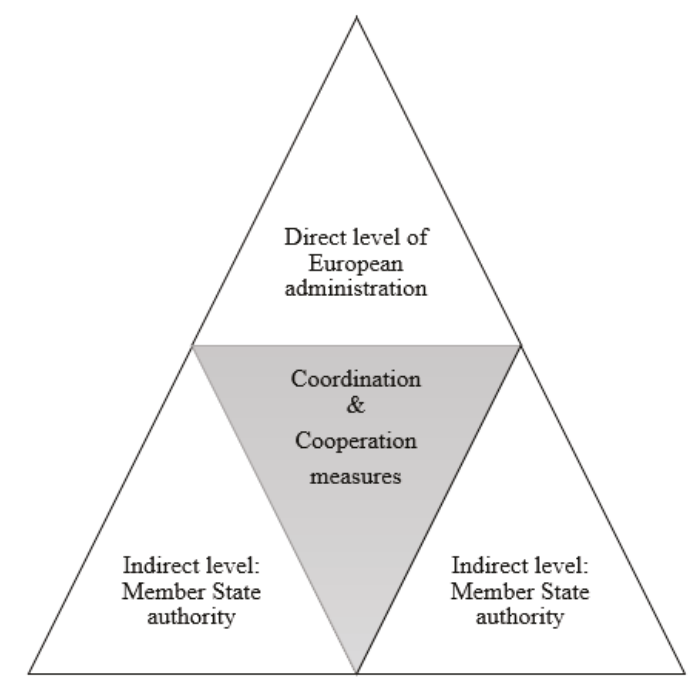

Source: Own.

Cooperation and coordination measures adopted under the new regime to facilitate consular protection for unrepresented EU citizens should enhance legal certainty as well as efficient cooperation and solidarity among consular authorities (Directive 2015/637, preamble (4)). 
The vertical and horizontal relationship of the actors basically relies on non-binding instruments or simply decided upon ad hoc basis. Therefore, the aim is to reveal if it can fit into a rule of law determined concept of European administration or not. To that end, first, the administrative law aspects of rule of law shall be seen clearly and then, by analysing the current legal regime including fundamental rights, procedural and institutional law, statements can be made on its status. In the point of view of citizens, the measures and the administrative procedural guarantees stand in the centre. For consular protection procedure, the consular law of the requested authority's State is to be applied, although the previous phase is currently non-transparent, and only soft law guidance are available which seriously challenge the possibility to rely on them as an obligation or to invoke them (see, Trubek et al. 2005, p. 2; cf. Ştefan, 2017, p. 203 and pp. 21626) although according to the rule of law requirements including the right to good administration (EU Charter, art. 41), the person shall enjoy a set of procedural guarantees.

Legal literature is also reticent on this issue as administration and the administrative procedure of consular protection, although it is an administrative service, is still a basically domestic issue, but the success of the evaluation of EU law lies in administration applying common constitutional principles (Lisbon Special European Council, 2000, para. 9 and 17; Drechsler, 2009, pp. 7-10) wishes to expand the scope to that end, although it does not answer significant jurisdictional and responsibility questions.

\section{Findings on the European administration of consular protection}

\subsection{Structural concerns of coordination and cooperation - rule of what?}

Consular protection in third States under the auspice of EU law is, in fact, a multi-level European administrative organisation (Dezső-Vincze, 2012, p. 490; Heidbreder, 2009, p. 5; Torma, 2011, p. 197; Kárpáti, 2011, p. 234; Koprič et al., 2011, pp. 1545-1546; Curtin and Egeberg, 2013, pp. 3032; cf. Hofmann, 2009 , p. 45) with composite administrative procedures (von Bogdandy and Dann, 2008, p. 215) whose normative is marked by the rule of law challenges.

Speaking about the European administration of consular protection under article 23 of TFEU/article 46 of EU Charter, the horizontal and vertical cooperation of the competent organs and authorities shall be examined as the consular policy of the EU is based on it. In a basic case, the unrepresented EU citizen has the right to turn to any available Member State's consular authority for assistance. The authority at site contacts the responsible authority of the alleged State of nationality to check the identity and leaving space for the national authority to proceed; the foreign consular authority proceeds the case only if the Member State of nationality cannot or will not do it. The financial background of the procedure depends on the consular law of the jurisdiction, 
then it is the issue of the concerned Member States and the Member State of nationality and its own national. In case of a crisis, that is natural or industrial catastrophes, terrorist attacks or any kind of situation when a mass of the EU citizens needs consular assistance on the territory of a third country, the supranational level of the European administration directly appears with the Commission as its vice-president, the HR/VP is responsible for foreign policy, including crisis management mechanisms (TEU, art. 26 (2); EEAS Decision, art. 4 (3) a)). The identity check round may be put aside due to necessity and time loss, although other cooperation forms appear if there are other represented Member States at the site, if there is an appointed Lead State among the represented Member States (Lead State Guidelines, art. 2.1-2.4) and the delegations of the EU displaced in the third State, which are hybrid administrative constructs that combine diplomatic and operational tasks, such as development cooperation and trade (Helly et al., 2014, p. 9; see also Reynaert, 2012. pp. 207-226) but have no competence to provide consular protection, appears, along with the competent units of the EEAS, which is a functionally autonomous body under the direction of the HR/VP (EEAS Decision art. 1.2; Lequesne, 2015, p. 36; Gatti, 2016, pp. 105190) to support consular authorities' work (Directive 2015/637, art. 10-11; 13).

To describe the institutional relation of them, it shall be highlighted first, that none of the supranational organs are neither entitled to perform authority acts nor to pursue consular protection. The cooperation of the competent institutions and organs is mainly based on coordination. Horizontal coordination is carried out at two main levels. The first one is a direct administrative level, where the coordination of all the foreign policy issues is the responsibility of the HR/NP (TEU, art. 26 (2)) assisted by the EEAS, which also has its own coordination system among its different divisions. (EEAS Decision, art. 4) The second level is the forum of the site. In situ coordination has three main potential actors each of them having their own coordination mechanism. The first actor responsible for coordination is (a) the local EU delegation in a complementary role (Austermann, 2014, p. 57). The second one is (b) the group of represented Member States who shall closely cooperate with each other and with the delegation and other potential bodies of the Commission (Directive $2015 / 637$, art. $10.1 ; 11$ ). In case of more represented one, a Member States can take on the role of the Lead State on a voluntary basis under conditions laid down in a guideline, but without defining legal tools to that end (Lead State Guidelines, intro. (2); (5)). Close cooperation in this context means sharing of information to ensure efficient assistance for the unrepresented citizens and coordinating contingency plans among themselves and with the EU delegation to ensure that unrepresented citizens are fully assisted in the event of a crisis (Directive 2015/637, Preamble (2), art. 13). Further details, like the assignment of one responsible actor to manage the process of an evacuation, for instance, and deal with the involvement of the EU capacities, is the subject of further intergovernmental negotiations of Member States (Directive 2015/637, preamble (19), art. 7 (2)-(3)). In addition, such negotiation does not create a right to give orders for the delegations or in reverse, nor does subordinate consular authorities to the EU organs in the system. 
Upon request by Member States' consular authorities, the delegations support the Member States in their diplomatic relations and in their role of providing consular protection to citizens of the Union in third countries on a resource-neutral basis (EEAS Decision art. 5(9); Helly et al., 2014, pp. 810). They can also request to be supported by existing intervention teams at the EU level, including consular experts, in particular, from unrepresented Member States, and by instruments such as the crisis management structures of the EEAS and the Union Civil Protection Mechanism (Directive 2015/637, art. 13 (4); UCPM Decision, art. 16.17; Gestri, 2012, p. 118). The Member States concerned should, whenever possible, coordinate such requests among each other and with any other relevant actor to ensure the optimal use of the Union Mechanism and avoid practical difficulties on the ground. The Lead State, if designated, should be in charge of coordinating any support provided for unrepresented citizens (Lead State Guidelines, 2).

To describe the relationship between the different levels and various actors of the European administration of consular policy, the words 'coordinate' and 'support' are often used. Even if none of these words are defined by any normative texts, they must not expressis verbis suggest obligation. The aim is to synthesize efforts but without the coercive force of persuasion or direct order to make obligations, although accountability, predictability, and common understanding are presumed (Lequesne, 2015, p. 46).

The system of European administration on consular protection lacks the classical hierarchical structure of state administration and vertical coordination is regulated by decision only in the case of the EEAS and its delegations. According to the relevant legal and non-legal acts of the EU acquis, none of the EU institutions or other bodies is entitled to give direct orders to consular authorities of Member States. It would reduce their autonomy and their consular tasks. The consular authorities stay under the direction of their domestic superior authority, although the Member States' authorities should closely cooperate and coordinate with one another and with the EU, in particular, the Commission and the EEAS, in a spirit of solidarity (TEU, art. 2; cf. TFEU 2221 (b); Solidarity Decision, art. 4; 5; Chronowski, 2017, p. 35, see also: Klamert, 2014, p. 3541).

Under these general principles, in the absence of harmonisation in material rules on foreign policy and consular protection, would vertical cooperation have an indirect impact making the EU organs a coercive power on external Member State organs? The principle of loyal cooperation might urge effective execution and evaluation of a fundamental right of citizenship to overrule the shortage on organisational rules but, in the meantime, neither the implementation of foreign policy, nor the charter may extend the field of application of the EU law or establish any new power or task for it, or modify powers and tasks as defined in the TEU-TFEU. The rules for the EEAS and foreign policy may not affect the existing legal basis, responsibilities, and powers of each Member State in relation to the formulation and conduct of the EU foreign policy, national diplomatic service, and relations with third countries (14. Declaration to the Treaties, EU Charter art. 51 (2); TEU, art. 40 (1); EEAS Decision, 
article 4 (3) (a); cf. TFEU, art. 352. see, Dashwood, 2009, p. 43). Meanwhile, many debates support the expansion of the delegations' competency to take over some administrative functions for example to issue Schengen visa and to ensure some basic consular protection measures (Balfour and Raik, 2013, pp. 3738). In the name of the subsidiary principle and the constitutional allocation of competences in the Treaties along with financial and institutional simplification prospects, the smaller States welcome the idea and would happily save some money with closing their consulates or being represented by the EU delegation where they were not before, but absolutely rejected by the dominant large States which are afraid of losing the rest of their external sovereignty and political interests by such a step (Lequesne, 2015, pp. 48-49; Whitman, 2015, p. 25). However, it shall be noted that all EU norms are pacta tertiis for third States, therefore consular protection can be practiced for nonnationals, that is on behalf of another State, upon appropriate notification to the receiving State, unless the receiving State objects (VCCR, art. 8), so for the sake of efficiency, according to Directive 2015/637, Member States are responsible to undertake the necessary measures in relation to third countries to ensure that consular protection can be provided on behalf of other Member States. In contrast, Directive 2019/997 empowers delegations to negotiate with third State the acceptance of the common EU format travel document and handle the specimens (Directive 2019/997, art. 13), so this consensual step at the drafting of the new rules for effectivity, in respect of proportionality and subsidiarity principles, is an approach towards the logical burden-sharing.

Summing up, the lack of transparent and pre-defined rules of institutional relationship is seems to show inconsistency with the requirements of rule of law and the gaps of rules may lead to jurisdiction problems and procedural consequences in the view of the responsibility of authorities and the evaluation of fundamental citizenship rights.

\subsection{Procedural concerns of cooperation - rules towards 'l'état de droit'}

In the view of the beneficiaries of the European consular protection policy, first, it shall be noted that an equal treatment clause is proclaimed (Poptcheva, 2014, pp. 171-173) but no harmonisation of consular law has been aimed, simply because of the lack of competences to do so. The relevant legal norms of the second pillar were not recognized as part of the EU legal order as they were adopted on an inter-governmental ground. Meanwhile, as acquis communautaire, they were to be respected, although they could never overcome the diversity of national regulations and foreign policies (CARE Final Report, 2010, pp. 2425). Later, the Lisbon Treaty brought major changes including new competencies to facilitate consular protection in the form of the directive with cooperation and coordination measures, but basically, the nature of assistance and the applied measure depends solely on the consular (domestic) law of the requested consular authority's Member State in each situation. Therefore, there is no uniform consular assistance service and no uniform pro- 
cedural law either, although the general scenario in case of a request is now settled, ie. how the Member States' diplomatic and consular authorities shall closely cooperate and coordinate with one another and with the EU organs to ensure the protection of unrepresented citizens (Directive 2015/637, art. 10). It is essential to highlight the fact that in case of distress, the obligation of the Member States is to give assistance, but not even a common emergency travel format cannot overrule consular law of Member States, if the authority is not empowered to issue such documents by their own domestic law.

The new regime introduced by Directive 2015/637 is based on solidarity, non-discrimination and respect for human rights and it refers to EU citizenship as a fundamental status and the rights inherent as special ones (Directive 2015/637, preamble (1)-(3)). However, it aims no intervention in international relations, the task to make consular protection of non-nationals possible are addressed to Member States. Meanwhile, details are not discussed, although the requirement of a proper administrative service for EU citizens is resulted from basic values of the EU concerning administrative procedures which shall be also evaluated, inter alia, the right to good administration, in case of breach of law the right to legal remedy, and also the right to respect of family life and the right to protection of personal data, which are priorities of the Directive 2019/997 (Directive 2019/997, preamble (22)). All are enlisted among the fundamental rights placed among primary sources of EU law (TEU art. 6 (3)) and although there are some concerns whether they are superior or not to other primary sources (Ziller, 2014, p. 347), it is undoubted that they are normative to all foreign services of the Member States that executes the EU's consular protection policy (EU Charter, art. 51.1). In addition, compared to the regime of Decision 95/553/EC, in the view of citizenship rights, the consular protection shall be provided to those family members as a derivative right, "who are not themselves citizens of the Union, accompanying unrepresented citizens in a third country, to the same extent and on the same conditions as it would be provided to the family members of the citizens of the assisting Member State, who are not themselves citizens of the Union, in accordance with its national law or practice" (Directive 2015/637, art. 5).

One may ask if it is compatible with the rule of law that in the territory of a third State, the same EU citizen and its accompanying family member may get different administrative services due to the different consular laws of Member States. The consular authority of Member State 'A' may ensure a higher level of assistance, the ' $B$ ' would refuse to ensure the service for the family member, while ' $C$ ' could cost three times more than the other one, although formally, all of them are consistent with the core provisions of the consular protection policy of the EU. The possible diversity of the content and the personal scope of service are aggravated by differences in other aspects of the service like pre-conditions, for example, there are states who insist on submitting a police report to prove the loss of passport while others do not require such a document. The fee of the service is also a key factor in this context as the Directive 2015/637 impose provisions only on the scenario of reimbursement and mutual solidary between Member States (Directive 2015/637 
(26)-(28), art. 14-15; annex I-II) and the EU ETD Proposal declares that States shall collect from the applicant such charges and fees as would normally be levied by them for issuing an emergency passport, although currently, it varies from 1,55 to 150 EUR (ETD Presidency reflection paper, pp. 910). Such differences may be eliminated by practical arrangements, local agreements and workshare agreements which would have significance mainly among the represented Member States within the same third States although some sort of standardisation would definitely serve a balanced service and predictability and reduce the chance of forum shopping. From the point of view of Member States, they formally do not violate their obligation of equal treatment, however, the lack of proactive steps towards workload share may reveal questions concerning the effect of rights (Rasmussen, 2017, p. 279).

In a particular third State, several Member States can be represented offering a variety of choice of forum for non-represented individuals as according to the directive in question, the individual has the right to turn to any of them. ${ }^{2}$ This may create forum shopping and an unequal burden on the chosen Member State. Here it is essential to reveal that being unrepresented means having no available representation in time and/or distance, so even if an EU citizen's nation-State is represented in a particular third State, it does not automatically mean that he/she is represented; the consular authorities shall take into account the circumstances of each particular case (Directive 2015/637, preamble (8)). The workload share arrangements shall be beneficial to citizens since they allow for better preparedness to ensure effective protection. Member State consular authorities that receive requests for protection should assess (a) whether, in a specific case, it is necessary to provide consular protection or (b) whether the case can be transferred to the embassy or consulate which is designated as competent according to any arrangement already in place. According to the present regime, Member States should notify the Commission and the EEAS of any such arrangement, which should be publicised by the EU and the Member States to ensure transparency for unrepresented citizens (Directive 2015/637, preamble (10)). These arrangements are either non-existents or the transparency is missing as on the Commission's designated website, no such information seems to be available for EU citizens. ${ }^{3}$ Even if in each and every third State there is an agreement of cooperation, the level of service stays colourful in different third States, although the harmonisation or standardisation of service is not aimed, while the clear, predictable and transparent administration of consular protection is not simply a desire but an obligation deriving from general administrative principles of EU law. As a general principle, the functioning of the EU is based on the rule of law, therefore good administration means that the institutions, bodies, offices, and agencies of the EU in carrying out their missions, shall have the support of an open, efficient and independent European administration (TFEU, art. 298 al 1). Thus, good administration 'must be ensured by the

2 To see the available representations, visit: https:/ec.europa.eu/consularprotection/content/ home_en (20.10.2019.)

3 See, Consular Protection, https://ec.europa.eu/consularprotection/content/home_en (20. 10.2019.) 
quality of legislation, which must be appropriate and consistent, clear, easily understood and accessible' (CM/Rec(2007)7, pp. 3-4; TEU art. 2; Pech, 2009, pp. 53-57). Therefore, the scenario stating that the assisting Member State and the unrepresented citizen's Member State of nationality should be able to agree on detailed arrangements for reimbursement of costs of consular protection within certain deadlines (Directive 2015/637, preamble (26)-(28); art. 7) shall also correspond to general provisions on citizenship procedural rights. Directive 2019/997 does not bring an innovation in this field, it also emphasises that Member States that receive an EU ETD applications should assess it on a case by case basis, whether it is appropriate to issue the EU ETD or if the case should be transferred to the embassy or consulate which is designated as competent under the terms of any arrangement already in place (Directive 2019/997, preamble (7)). A crisis may justify flexibility and increase the level of discretion by the authority, atthough such power must also have clear legal boundaries and be subject to several constitutional and administrative law standards, such as objectivity and consistency in application (SIGMA 27, 1999, pp. 8-14; Ponce, 2005, pp. 553-554), too, just as it is provided by the current regime: in the view of administrative procedural requirements "[t]o fill the gap caused by the absence of an embassy or consulate of the citizen's own Member State, a clear and stable set of rules should be laid down. Existing measures also need to be clarified to ensure effective protection" (Directive 2015/637, preamble (7), emphasis added by Author).

Meanwhile, compared to Directive 2015/637, Directive 2019/997 already recognized that along respecting competency limits, (cf. EU ETD Proposal, preamble (9)) it is necessary to avoid fragmentation and resulting in decreased acceptance of emergency travel documents issued by Member States to unrepresented citizens, be better achieved at the EU level. Therefore, in addition to the Member State roles and responsibility centric Directive 2015/637, Directive 2019/997 empowers the EU delegations in third States to notify the Third State authorities about the EU emergency travel document issuing practice and handle the specimens and negotiate to enhance is recognition (Directive 2019/997, preamble (18); art. 13). It also establishes generally accepted ICAO safety measures to increase the international acceptance of the EU ETD (Directive 2019/997, art. 8. 2-3.; annex II) An internationally accepted form of travel document serves better its recipients and reduces the risk of rejection at border control while the recognition of the EU as unity may also be achieved.

In the view of the principle of good administration, Directive 2019/997 seems to give the chance for a transparent, reliable and predictable service without prejudice to the domestic laws of Member States. In contrast, with the pure scenario ie. listing the procedural steps in case of a submitted request for consular assistance of a non-represented citizen, the Directive 2019/997 contains exact deadlines for each phase of the procedure (Directive 2019/997, art. 4). Without any interference to domestic laws, the EU ETD is willing to overlap the inter-national procedural phase that used to be ignored due to competency issues and was a marginal subject of soft law guidance. As for procedural guarantees, Directive 2019/997 also remains silent, although the general principles 
of EU law including the EU Charter provisions stand as background. Among the most related ones, the right to good administration shall be discussed.

Being an umbrella right as a collection of procedural requirements, its elements are not unknown for democratic administrative procedure codes of Member States, however, domestic law does not extend to horizontal and vertical procedural stages, so the effective application of these rights may be questioned in these phases. Jurisdiction issues and legal remedy options would be crucial and not just for EU citizens, but also for family members. The substantial part of their consular protection rights is even more unpredictable, although the same procedural background could create a sort of unity. Under the right to good administration, the family member is also entitled to the same procedural guarantees given the fact that it enables every person and not just EU citizens. All in all, even in the lack of administrative procedural law code, the EU Charter provisions serve as general background for administrative procedures, although their application and enforcement may challenge the procedure in time and costs. The cooperation mechanism should be based on legally binding sources to make the procedure predictable and transparent with clearly defined tasks and competences, aspects of responsibility, applicable law and finally: supervision and legal remedy (EU Charter, art. 47; Model Rules, VI-3.; Varga Zs, 2014, p. 547). Currently, these requirements are fulfilled only partially.

It is necessary to establish a simplified procedure for cooperation and coordination between the assisting Member State and the unrepresented citizen's Member State of nationality but at the same time, it is crucial to maintain a sufficient flexibility in exceptional cases. In crisis situations, the assisting Member State should be able to issue EU ETDs without prior consultation of the Member State of nationality. In these situations, the assisting Member State should notify the Member State of nationality as soon as possible of the assistance granted on its behalf to ensure that the Member State of nationality is adequately informed (Directive 2019/997, art. 4.6). Again emphasized, in case of practicing discretionary power, the authorities are also engaged within the rule of law, therefore, the limitations and the modes of discretion shall also correspond to the same values and same procedural guarantees, including the availability of legal remedies. The EU Charter does not establish any new power or task for the EU, or modify powers and tasks defined by the Treaties (EU Charter, art. 51.2), but to establish the background for the evaluation of the content of the EU Charter as well as the content of any rights issuing from EU norms is the duty of Member States. Therefore, the existing powers to create regulations of administrative cooperation (TFEU, art. 197) and further cooperation and coordination directives to facilitate consular protection (TFEU, art. 23 al 2) are also available to further common steps and in case of the latter, to establish in domestic legal order the necessary modifications to meet such requirements as the details of consular protection and its procedures are regulated in many ways (CARE report, 2010, pp. 580-585). The effective implementation of the above-mentioned provisions (duty of consistent interpretation or 'indirect effect') requires positive action (Chalmers and 
Tomkins, 2007, pp. 381-394; Klamert, 2014, pp. 125-138). "In the absence of EU rules on the matter, it is for the national legal order of each Member State to establish procedural rules for actions intended to safeguard the rights of individuals, in accordance with the principle of procedural autonomy (...)" (Case C-3/16, point 43).

All in all, it seems that upon the fundamental rights implications and their effective implementation to a better administrative service under the auspice of rule of law, the development of the policy seems to be dynamic and Member States shows a willingness to accept measures in secondary legal source to that end, as it is shown by the existence of Directive 2019/997.

\section{Concluding remarks}

Consequences seem logical and obvious, but it shall be noted that domestic administrative law does not expand beyond their territorial scope and the EU has restricted legislative competences which is different in diverse policies, although administrative cooperation measure in the form of regulation has gained legacy since the Lisbon Treaty but measures taken upon these provisions shall not result as prejudice on national administrative laws (Lisbon Treaty, 76/D; TFEU 197). This latter condition is clearly a limitation on the legislator. In addition, it shall be noted that even if there are relevant principles, they cannot create competence and cannot be substituted for missing empowerment provisions as measures taken at the EU level must also comply with the principle of subsidiarity (McDonnell, 2014, p. 66). Principles fill the legal gaps and direct interpretation to achieve the common goal: evaluation of the EU goals, therefore, the rule of law is the encompass in European administration when the balance between the proper and effective execution of the acquis and Member State sovereignty is at stake, and rule of law is also the motor that keeps the legal development in action.

The European administrative organisation is a multilevel structure with different networks of authorities in different policies (Terpan, 2013, pp. 33-34) and being the major value in the $\mathrm{EU}$, the rule of law shall be motor of it. The EU is based on the transfer of power from the Member States and the main cohesive force for all the policies among the levels of European administration is coordination at the supranational centre but basically the authority power lies in Member States' authorities. It is also true for the European consular protection structure. The policy itself is at the crossroad of common foreign and security policy, citizenship and fundamental rights protection and also concerns public administrative law and the cooperation of authorities at the horizontal and vertical levels. The challenging part is the vertical relationship of the actors. In fact, at the local level, only delegations are under the effective direction of the HR/VP and the president of the EEAS, who both represent the EU interests, but the consular tasks are performed by the consular authorities of Member States because of they are empowered to do so, however, these latter category falls outside their scope. Sincere cooperation, loyalty, and solidarity together with coordination are important functional principles of 
European administrative structure but principles cannot create competence and cannot provide a direct legal basis for a measure at the EU level. Indeed, principles primarily indicate how a competence should be used, and therefore they guide those who fulfil obligations. Therefore, the insufficient provisions on inter-institutional relations can basically challenge the consistency with the rule of law and a proper functioning under its auspice. In another aspect, from the beneficiary side, creating a basis for a better administrative service with a more coherent, transparent and reliable legal framework than in the previous regime is essential not only in the effectivity of consular protection policy of the EU but in the development of normative rules of European administration: in an organisational as well as a procedural aspect. The development of the normative rules of consular protection policy of the EU clearly shows a certificate for this aspect. By involving the Commission and its related organs to perform external policy tasks justified by subsidiarity and proportionality principles, the organisational structure of a once purely domestic area of external administration, the consular protection, the European administration is growing. Meantime, its normative background is also developing as the intermediate phase, the connection of vertical and mainly the horizontal cooperation is currently purely regulated by predictable and transparent binding secondary sources. In consular protection issues it is also framed by soft law, therefore the entry into force of the Directive $2019 / 997^{4}$ will mean a quality change and a step towards a better administrative service which is closer to the principles and requirements of an "open, efficient and independent European administration" (TFEU, art. 298.1) and to the legitimate expectation of every person who shall enjoy all the guarantees evolved in the right to good administration and other benefits of the EU Charter. The drafting of this directive proposal calls the attention to the importance of effectivity which is essential for the proper functioning of the EU, while the insurance of benefits related to the European Union citizenship urges Member States to increase Europeanisation in certain issues, while it is also recognized that the neglected phase of horizontal interaction of the competent authorities shall be regulated in binding secondary sources of EU law. The die is cast, the path is given, the first steps are taken; the rule of law principle further serves as a compass.

4 Member States shall adopt and publish, by 24 months of the adoption of the additional technical specifications the laws, regulations and administrative provisions necessary to comply with Directive 2019/997. They shall immediately communicate the text of those provisions to the Commission. They shall apply those measures from 36 months after the adoption of the additional technical specifications. (Directive 2019/997 art. 19.) 


\section{References}

14. Declaration concerning the common foreign and security policy. OJ C 202, 7. 6. 2016, p. 343.

Decision 95/553/EC, OJ L 314, 28. 12. 1995, pp. 73-76. [No longer in force]

Decision 96/409/CSFP OJ L 168, 6. 7. 1996, pp. 4-11.

Austermann, F. (2014). European Union Delegations in EU Foreign Policy. A Diplomatic Service of Different Speeds. Basingstoke: Palgrave Macmillan.

Balfour, R. and Raik, K. (2013). Equipping the European Union for the $21^{\text {st }}$ Century. National Diplomacies, the European External Action Service and the Making of EU Foreign Policy. FIIA Report 36. At <https://www.fiia.fi/en/ publication/equipping-the-european-union-for-the-21st-century>, accessed 18 March 2020.

Baver, M.W. and Trondal, J. (2015). The Administrative System of the European Union. In M.W Bauer and J. Trondal, eds., The Palgrave Handbook of the European Administrative System. Basingstoke: Palgrave Macmillan, p. 128.

Bogdandy, von A. and Dann, P. (2008). International Composite Administration: Conceptualizing Multi-Level and Network Aspects in the Exercise of International Public Authority. German Law Journal, 9(11), pp. 2013-2039.

Bogdandy, von A. (2008). General Principles of International Public Authority: Sketching a Research Field. German Law Journal, 9(11), pp. 1909-1939.

C-3/16, Lucio Cesare Aquino v Belgische Staat, ECLI: EU:C:2017:209.

CARE Final Report. (2010). Consular and Diplomatic Protection. Legal Framework in the EU Member States. At <http://www.careproject.eu/images/stories/ ConsularAndDiplomaticProtection.pdf>, accessed 18 March 2020.

Chalmers, D. and Tomkins, A. (2007). European Union Public Law. Text and Materials. Cambridge: Cambridge University Press.

Chronowski, N. (2017). Dignity and Solidarity - Lost in Transition. The Case of Hungary. MTA Law Working Papers, no. 15. At <https://jog.tk.mta.hu/ uploads/files/2017_15_Chronowski.pdf>, accessed 18 March 2020.

CM/Rec. (2007). Recommendation CM/Rec (2007)7 of the Committee of Ministers to member states on good administration. Council of Europe, 20 June 2007 at the 999bis meeting of the Ministers' Deputies.

Consular Guidelines on the protection of EU citizens in third countries adopted by the COCON and endorsed by the PSC 15613/10, of 5 November 2010.

Corkin, J. and Boeger, N. (2014). Endogenous Transformations in European Public Administration: Soft-Law, Transnationally Networked Governance as a Self-Reinforcing Trend. In E. Bohne et al., eds., Public Administration and the Modern State. Assessing Trends and Impact. Basingstoke: Palgrave Macmillan, pp. 223-238.

Council Decision 2014/415/EU, OJ L 192, 1. 7. 2014, pp. 53-58.

Curtin, D. and Egeberg, M. (2013). Towards a New Executive Order in Europe? London: Routledge.

Dashwood, A. (2009). Article 308 EC as the Outer Limit of Expressly Conferred Community Competence. In C. Barnard and O. Odudu, eds, The Outer Limits of European Law. Oxford: Hart Publishing, pp. 35-44.

Decision 1313/2013/EU, OJ L 347, 20. 12. 2013, pp. 924-947.

Dezső, M. and Vincze, A. (2012). Magyar alkotmányosság az európai integrációban. Budapest: HvgOrac. 
Directive 2015/637, OJ L 106, 24. 4. 2015, pp. 1-13.

Directive 2019/997, OJ L 163, 20. 6. 2019, pp. 1-12.

Drechsler, W. (2009). Towards a Neo-Weberian European Union? Lisbon Agenda and Public Administration. Halduskultuur, 10, pp. 6-21.

EEAS Decision. Council Decision 2010/427/EU, OJ L 201, 3. 8. 2010, pp. 30-40.

ETD Presidency reflection paper 2015, Emergency Travel Document (ETD) - Presidency reflection paper. COCON 14, CFSP/PESC 523, COTRA 13, 11955/15, Brussels, 17 September 2015.

EU Charter of Fundamental Rights of the European Union. OJ C 326, 26. 10. 2012, pp. 391-407.

Galetta, D. et al., eds. (2014). ReNEUAL Model Rules on EU Administrative Procedure. Book VI - Administrative Information Management. At <http:// www.reneual.eu/images/Home/BookVlinformation_management_online publication_individualized_final_2014-09-03.pdf>, accessed 18 Mārch $20 \overline{20}$.

Gatti, M. (2016). European External Action Service: Promoting Coherence through Autonomy and Coordination, Leiden: BRILL.

Gestri, M. (2012). EU Disaster Response Law: Principles and Instruments. In A. de Guttry, ed., International Disaster Response Law. The Hague: Asser, pp. 106-128.

Guidelines for further implementing a number of provisions under Decision 95/553/EC. Brussels, 24 June 2008, 11113/08, PESC 833 COCON 10.

Guidelines on consular protection of EU citizens in third countries. Brussels, 5 November 2010, 15613/10. COCON 40 PESC 1371.

Guidelines on Consular Protection of EU Citizens in Third Countries. PESC 534 COCON 14 10109/2/06 REV 2 Brussels, 16 June 2006.

Heidbreder, E. G. (2009). Structuring the European Administrative Space: Channels of EU Penetrations and Mechanisms of National Chance. KFG Working Paper Series, No. 5.

Helly, D. et al. (2014). A Closer Look into EU's External Action Frontline: Framing the Challenges ahead for EU Delegations. European Centre for Development Policy Management, Note, No. 62.

Hofmann, H.C.H. (2009). Which Limits? Control of Powers in an Integrated Legal System. In C. Barnard and O. Odudu, eds., The Outer Limits of European Law. Oxford: Hart Publishing, pp. 45-62.

Hofmann, H.C.H. (2012). The future of Article 298 TFEU. Administrative procedures for EU institutions and bodies and integrated administration in the EU. Presentation for the EU Ombudsman/ReNEUAL conference "Towards an EU administrative procedure law?", Brussels, 15-16 March 2012. At <http://www.reneual.eu/images/Events/ED_Conference_ March2012/6.6.pdf>, accessed 18 March 2020.

Kárpáti, O. (2011). Az európai közigazgatási tér kialakulása I. Publicationes Universitatis Miskolcinensis Sectio. Juridica et Politica, 29(1) pp. 229-247.

Klamert, M. (2014). The Principle of Loyalty in EU Law. Oxford: Oxford University Press.

Koprić, I. et al. (2011). Good Administration as a Ticket to the European Administrative Space. Zbornik PFZ, 61(5) pp. 1515-1560.

Lead State Guidelines. 2008/C 317/06, OJ C 317, 12.12.2008, pp. 6-8.

Lequesne, C. (2015). At the Center of Coordination: Staff, Resources and Procedures in the European External Action Service and in the Delegations. 
In R. Balfour et al., eds. The European External Action Service and National Foreign Ministries. Convergence or Divergence? Farnham: Ashgate, pp. 45-44.

Maastricht Treaty. Treaty on European Union OJ C 191, 29.7.1992, pp. 1-112.

McDonnell, A. (2014). Solidarity, Flexibility, and the Euro-Crisis: Where Do Principles Fit In? In L. S. Rossi and F. Casolari, eds., The EU after Lisbon. Amending or Coping with the Existing Treaties? Heidelberg: Springer, pp. 57-91.

Møller, J. and Skaaning, S. E. (2014). The Rule of Law Definitions, Measures, Patterns and Causes. Basingstoke: Palgrave Macmillan.

Pech, L. (2009). The Rule of Law as a Constitutional Principle of the European Union. New York: Jean Monnet Working Paper, No. 4.

Ponce, J. (2005). Good Administration and Administrative Procedures. Indiana Journal of Global Legal Studies, 12(2), pp. 553-554.

Poptcheva, E.M. (2014). Consular Protection Abroad: A Union Citizenship Fundamental Right? Brussels: PIE Peter Lang.

Rasmussen, S. B. (2017). Constructing the European Demos through External Action? The Case of Consular Assistance to EU Citizens. In B. P. de las Heras, ed., Democratic Legitimacy in the European Union and Global Governance: Building a European Demos. Basingstoke: Palgrave Macmillan, pp. 259-284.

Reynaert, V. (2012). The European Union's Foreign Policy since the Treaty of Lisbon: The Difficult Quest for More Consistency and Coherence. The Hague Journal of Diplomacy, 7(2), pp. 207-226.

Senden, L. A. J. (2005). Soft law and its implications for institutional balance in the EC. Utrech Law Review, 1 (1), pp. 79-99.

SIGMA 27. European Principles for Public Administration. SIGMA Papers: No. 27, CCNM/SIGMA/PUMA (99)44/REV1. 1999.

Ştefan, O. (2017). Soft Law and the Enforcement of EU Law. In A. Jakab and D. Kochenov, eds., The Enforcement of EU Law and Values. Ensuring Member States' Compliance. Oxford: Oxford University Press, pp. 200-217.

Terpan, F. (2013). Soft Law in the European Union - The Changing Nature of EU Law. Sciences Po Grenoble, Working paper, No. 7. At <https://halshs.archivesouvertes.fr/halshs-00911460/document>, accessed 18 March 2020.

TEU. Consolidated version of the Treaty on European Union. OJ C 326, 26. 10. 2012, pp. 13-390.

TFEU. Consolidated version of the Treaty on the Functioning of the European Union, OJ C 326, 26. 10. 2012, pp. 47-390.

The Lisbon Special European Council. Towards a Europe of Innovation and Knowledge. Presidency Conclusions, Lisbon European Council, 23. 3. and 24. 3. 2000. At <http://eur-lex.europa.eu/legal-content/EN/ TXT/?uri=uriserv:c10241>, accessed 18 March 2020.

Torma, A. (2011). Az Európai Közigazgatási Térségről - magyar szemmel. Miskolci Jogi Szemle, 6, pp. 196-210.

Treaty of Lisbon amending the Treaty on European Union and the Treaty establishing the European Community, signed at Lisbon, 13 December 2007. OJ C 306, 17. 12. 2007, pp. 1-271.

Trubek, D. M. et al. (2005). "Soft Law," "Hard Law," and European Integration: Toward a Theory of Hybridity. University of Wisconsin. Legal Studies Research 
Paper, No. 1002. At <https://papers.ssrn.com/sol3/papers.cfm?abstract_ id=855447>, accessed 18 March 2020.

Varga, A. (2014). Gyorsértékelés az európai közigazgatási eljárási modellszabályokról. Magyar Jog, 61(10), pp. 545-555.

VCCR, Vienna Convention on Consular Relations, Vienna, 24. 4. 1963, 596 UNTS 261.

Verdier, P-H. (2009). Transnational Regulatory Networks and Their Limits. The Yale Journal of International Law, 34(1), pp. 114-172.

Whitman, R. (2015). Europe's Changing Place in the World and Challenges to European Diplomacy. In R. Balfour et al., eds., The European External Action Service and National Foreign Ministries. Convergence or Divergence? Farnham: Ashgate, pp. 17-30.

Ziller, J. (2014). Hierarchy of Norms: Hierarchy of Sources and General Principles. In U. Becker et al., eds., European Union Law' Verfassung und Verwaltung in Europa Festschrift für Jürgen Schwarze zum 70. Geburtstag. BadenBaden: Nomos Verlagsgesellschaft, pp. 334-352. At <https://ssrn.com/ abstract=2467982>, accessed 18 March 2020. 